\title{
IMPLEMENTASI PENDIDIKAN LINGKUNGAN HIDUP SEBAGAI KURIKULUM MUATAN LOKAL EKOPEDAGOGI DALAM MEMBANGUN KARAKTER SISWA DI SDN LOWOKWARU 2 MALANG
}

\author{
Nia Hidayanti' ${ }^{1}$ Zainul Abidin ${ }^{2}$, Arafah Husna ${ }^{3}$ \\ Universitas Negeri Malang \\ E-mail:niahida88@yahoo.com
}

\begin{abstract}
ABSTRAK
Penelitian ini bertujuan untuk mendeskripsikan tujuan, isi, sumber belajar, proses pembelajaran, dan penilaian pembangunan karakter dari kurikulum muatan lokal ekopedagogi PLH di SDN Lowokwaru 2. Penelitian ini merupakan penelitian deskriptif kualitatif. Teknik pengumpulan data yang digunakan adalah observasi partisipan, wawancara mendalam, dan dokumentasi. Keabsahan data diuji dengan uji kredibitasi dan uji dependability. Kegiatan analisis data dimulai dari pengumpulan data hasil observasi, wawancara, dan dokumentasi, penginterpretasian data, dan pengecekan keabsahan data. Hasil dari penelitian menunjukkan bahwa : (1) Tujuan kurikulum muatan lokal ekopedagogi PLH di sekolah ini adalah menerapkan sekolah berbudaya peduli lingkungan dan membekali siswa supaya bertanggung jawab dalam kegiatan pelindungan, pelestarian, dan pencegahan perusakan lingkungan dan sumber daya alam, serta pelestarian fungsi lingkungan di sekolah. (2) Isi kurikulum muatan lokal ekopedagogi PLH adalah pengintegrasian materi mengenai lingkungan hidup dalam indikator pembelajaran dan kegiatan pembelajaran di berbagai mata pelajaran yang sesuai untuk diintegrasikan. (3) Sumber belajar yang digunakan pada saat Pendidikan Lingkungan Hidup adalah buku tematik, lingkungan sekitar, dan teladan perilaku guru. (4) Proses pembelajaran muatan lokal ekopedagogi PLH di SDN Lowokwaru 2 dilakukan secara terintegrasi. Metode pembelajaran yang digunakan adalah metode ceramah, demonstrasi, diskusi, tanya jawab, penugasan, permainan, dan bermain peran. Namun penggunaan media pembelajaran di SDN Lowokwaru 2 belum dilaksanakan secara optimal. (5) Penilaian pembangunan karakter siswa dalam muatan lokal ekopedagogi PLH di SDN Lowokwaru 2 menggunakan penilaian otentik yang diambil dari nilai tugas, laporan, dan pengamatan kepada setiap siswa menggunakan catatan anekdot.
\end{abstract}

Kata kunci : pendidikan lingkungan hidup, kurikulum, muatan lokal ekopedagogi, membangun karakter siswa

\section{PENDAHULUAN}

Lingkungan hidup merupakan salah satu isu yang menjadi tantangan tersendiri bagi Indonesia. Berbagai masalah lingkungan hidup sering terjadi akibat dari penurunan kualitas lingkungan yang disebabkan oleh tingkah laku manusia. Manusia memiliki tingkat kepedulian yang rendah terhadap lingkungan hidup yang salah satu faktornya disebabkan karena kurang optimalnya pendidikan karakter yang diberikan dalam peningkatan kepedulian terhadap lingkungan hidup.

Pendidikan karakter diperlukan untuk mengupayakan peningkatan kepedulian manusia terhadap lingkungan hidup. Penguatan pendidikan karakter diharapkan dapat mewujudkan kesadaran lingkungan dengan menciptakan lingkungan belajar yang ideal untuk proses pembelajaran dan kegiatan untuk menyadarkan warga sekolah agar peduli lingkungan, sehingga di masa depan dapat ikut bertanggung jawab dalam pelestarian lingkungan hidup dan pembangunan berkelanjutan.

Saat ini tengah marak diterapkan Pendidikan Lingkungan Hidup (PLH) di sekolah. Penerapan PLH dilaksanakan dengan berbeda, ada sekolah yang menerapkan dengan diintegrasikan dalam mata pelajaran lain, ada pula sekolah yang menerapkan dalam kegiatan ekstrakurikuler dan dimasukkan sebagai muatan lokal, serta sekolah yang memberikan jam pelajaran khusus untuk pembelajaran Pendidikan Lingkungan Hidup. Pendidikan Lingkungan Hidup 
diberikan kepada siswa agar terbentuk karakter siswa yang peduli lingkungan dan terbentuk lingkungan sekolah yang kondusif sehingga proses pembelajaran bisa berjalan dengan baik. Pembelajaran PLH sebaiknya sudah diberikan sejak siswa berada di Sekolah Dasar (SD), dengan demikian akan terbentuk kesadaran akan perilaku hidup bersih dan pentingnya menjaga lingkungan yang diharapkan siswa akan menerapkannya di luar sekolah juga.

Berdasarkan Undang-Undang RI Nomor 20 Tahun 2003 tentang Sistem Pendidikan Nasional, terdapat pesan bahwa pada kurikulum pendidikan dasar dan menengah wajib memuat muatan lokal. Berdasarkan Peraturan Menteri Pendidikan dan Kebudayaan Republik Indonesia Nomor 79 tahun 2014 tentang Muatan Lokal Kurikulum 2013, dijelaskan bahwa "muatan lokal adalah bahan kajian atau mata pelajaran pada satuan pendidikan yang berisi muatan dan proses pembelajaran tentang potensi dan keunikan lokal yang dimaksudkan untuk membentuk pemahaman peserta didik terhadap keunggulan dan kearifan di daerah tempat tinggalnya". Muatan lokal diajarkan bertujuan untuk mengenalkan dan menanamkan rasa cinta pada lingkungan alam, sosial, budaya, dan spiritual. Di dalam kurikulum, muatan lokal dapat menjadi pelajaran yang berdiri sendiri atau menjadi bahan kajian suatu mata pelajaran yang ada (Abdullah, 2006:265). Apabila muatan lokal menjadi pelajaran yang berdiri sendiri, maka proses pembelajaran dilakukan dengan alokasi waktu tersendiri, sedangkan apabila menjadi bahan kajian mata pelajaran maka muatan lokal tidak memiliki jam pelajaran tersendiri dan hanya dijadikan tambahan untuk bahan kajian yang sudah ada.

SDN Lowokwaru 2 merupakan sekolah berpredikat adiwiyata tingkat nasional yang berada di Jl. Tretes no. 3 Lowokwaru, Kecamatan Lowokwaru, Kota Malang. Sekolah ini merupakan Sekolah Dasar di Kota Malang yang menjadi pemenang adiwiyata tingkat nasional pada tahun 2017. Berdasarkan hasil penjajakan awal peneliti terhadap sekolah, visi dan misi dari SDN Lowokwaru 2 juga menunjukkan bahwa sekolah tersebut menjunjung tinggi pentingnya menjaga lingkungan hidup. Visi dari SDN Lowokwaru 2 yang dimaksud adalah menjadi sekolah sebagai tempat tumbuh kembang peserta didik yang unggul dalam imtaq, IPTEK, berbudi pekerti luhur, serta peduli dan berbudaya lingkungan. Sejalan dengan visi tersebut, misi dari SDN Lowokwaru 2 yang dimaksudkan adalah membudayakan warga sekolah yang aktif dalam kegiatan perlindungan lingkungan sumber daya alam, membudayakan warga sekolah yang aktif dalam kegiatan pelestarian lingkungan sumber daya alam, dan membudayakan warga sekolah yang aktif dalam kegiatan pencegahan perusakan lingkungan sumber daya alam. SDN Lowokwaru 2 sebagai sekolah berwawasan lingkungan membentuk kelompok kerja (POKJA) yaitu POKJA energi dan kantin, penanganan limbah cair, sampah dan kompos, daur ulang dan produk unggulan, air dan sanitasi, greenhouse pembibitan, pembudidayaan lele, biopori, dan kamar mandi. Adanya POKJA-POKJA tersebut membantu untuk memperjelas masing-masing tugas dan prioritas dari setiap kelompok Di sekolah ini juga rutin diadakan lomba kebersihan, kerapian, dan pemenuhan sarana prasarana standart kelas.

Berdasarkan pendeskripsian dari penjajakan awal terhadap SDN Lowokwaru 2, maka peneliti memilih sekolah tersebut menjadi lokasi penelitian yang akan dikaji dan dianalisis mengenai implementasi pendidikan lingkungan hidup sebagai kurikulum muatan lokal ekopedagogi dalam menbangun karakter siswanya. Tujuan dari penelitian ini adalah mendeskripsikan tujuan, isi, sumber belajar, proses pembelajaran, dan penilaian pembangunan karakter siswa pada kurikulum muatan lokal ekopedagogi Pendidikan Lingkungan Hidup di SDN 
Lowokwaru 2.

\section{METODE PENELITIAN}

Metode yang digunakan dalam penelitian ini adalah deskriptif kualitatif dengan subjek penelitian adalah kepala sekolah, koordinator kurikulum, guru, dan siswa. Teknik pengumpulan data yang digunakan adalah observasi partisipan, wawancara mendalam, dan dokumentasi. Keabsahan data diuji dengan uji kredibitasi dan uji dependability. Kegiatan analisis data dimulai dari pengumpulan data hasil observasi, wawancara, dan dokumentasi, penginterpretasian data, dan pengecekan keabsahan data.

\section{HASIL DAN PEMBAHASAN}

\section{Tujuan Kurikulum Muatan Lokal Ekopedagogi Pendidikan Lingkungan Hidup}

Berdasarkan hasil penelitian, tujuan kurikulum muatan lokal ekopedagogi Pendidikan Lingkungan Hidup (PLH) adalah :

1. Menerapkan sekolah yang berbudaya peduli lingkungan dengan wujud warga sekolah yang bertanggung jawab dalam kegiatan pelindungan, pelestarian, dan pencegahan perusakan lingkungan dan sumber daya alam, lewat tata kelola sekolah yang baik supaya dapat mendukung pembangunan berkelanjutan.

2. Membekali siswa tentang kegiatan perlindungan, pelestarian, dan pencegahan perusakan lingkungan dan sumber daya alam, serta pelestarian fungsi lingkungan di sekolah.

Perumusan tujuan kurikulum muatan lokal ekopedagogi Pendidikan Lingkungan Hidup di SDN Lowokwaru 2 ini telah sejalan dengan pernyataan Sukmadinata (2010) yang menyatakan bahwa tujuan kurikulum hendaknya dibuat berdasarkan perkembangan tuntutan, kebutuhan, dan kondisi masyarakat, serta didasari oleh pemikiran-pemikiran dan terarah untuk pencapaian nilai-nilai filosofis terutama falsafah negara. Saat ini memang masyarakat memiliki tingkat kepedulian yang rendah terhadap lingkungan hidup, sehingga tujuan kurikulum yang diberlakukan di SDN Lowokwaru 2 telah sesuai dengan tuntutan, kebutuhan, dan kondisi masyarakat serta mendukung revolusi karakter bangsa yang saat ini dicanangkan oleh pemerintah.

\section{Isi Kurikulum Muatan Lokal Ekopedagogi Pendidikan Lingkungan Hidup}

Isi kurikulum muatan lokal ekopedagogi Pendidikan Lingkungan Hidup (PLH) di SDN Lowokwaru 2 diperoleh dari teknik integrasi dengan mengembangkan karakter peduli lingkungan. Kurikulum yang diterapkan di sekolah ini sudah sesuai dengan pernyataan Kementerian Pendidikan Nasional (2010:18) yang menyatakan bahwa pengembangan nilai-nilai pendidikan budaya dan karakter bangsa dilakukan dengan pengintegrasian dalam mata pelajaran, dan di dalamnya termasuk pula pendidikan karakter peduli lingkungan melalui Pendidikan Lingkungan Hidup. Teknik integrasi yang diterapkan di sekolah ini dengan melakukan pengintegrasian Pendidikan Lingkungan Hidup dalam indikator pembelajaran dan kegiatan pembelajaran. Langkah-langkah pengintegrasian tersebut ialah mengkaji dan menganalisis Kompetensi Inti dan Kompetensi Dasar, menjabarkan Kompetensi Inti dan Kompetensi Dasar menjadi rumusan indikator pembelajaran, menganalisis kedalaman materi dari masing-masing indikator, menganalisis muatan Pendidikan Lingkungan Hidup yang dapat diintegrasikan dengan indikator, menganalisis muatan Pendidikan Lingkungan Hidup yang dapat disisipkan dalam skenario pembelajaran dari indikator pembelajara tertentu, memilih 
model pembelajaran terpadu yang relevan dengan hasil analisis, mengintegrasikan muatan PLH dalam indikator dengan menggunakan model pembelajaran tematik terpadu, merumuskan hasil integrasi menjadi indikator-indikator pembelajaran terpadu, menyisipkan muatan PLH dalam skenario pembelajaran, dan menyusun program pembelajaran berupa silabus dan RPP.

\section{Sumber Belajar Muatan Lokal Ekopedagogi Pendidikan Lingkungan Hidup}

Sumber belajar untuk muatan lokal ekopedagogi Pendidikan Lingkungan Hidup (PLH) di SDN Lowokwaru 2 Malang adalah buku tematik, lingkungan sekitar, dan teladan perilaku guru. Pemilihan sumber belajar ini sudah sesuai dengan Permendikbud no. 22 Tahun 2016 tentang Standar Proses Pendidikan Dasar dan Menengah yang menyebutkan bahwa sumber belajar bisa dalam bentuk buku, media cetak dan elektronik, alam sekitar, dan sumber belajar lainnya yang relevan. Tidak adanya modul khusus Pendidikan Lingkungan Hidup bagi siswa disebabkan muatan lokal ekopedagogi Pendidikan Lingkungan Hidup di sekolah ini bukanlah pelajaran monolitik melainkan terintegrasi. Dengan diberlakukannya Pendidikan Lingkungan Hidup yang diberikan secara terintegrasi inilah, guru memiliki peran penting dalam proses pembelajaran. Guru dituntut kreatif dalam menyediakan sumber belajar untuk Pendidikan Lingkungan Hidup baik menggunakan buku tematik, lingkungan sekitar, dan dalam berperilaku untuk menjadi teladan bagi siswa.

Selain pemodelan atau pemberian contoh dari guru, SDN Lowokwaru 2 juga melakukan model penciptaan kondisi dengan pembiasaan bagi siswa untuk rutin setiap pagi baris sebelum masuk ke dalam kelas, membaca doa, menyanyikan lagu wajib nasional, pembacaan visi, misi, dan tujuan sekolah, senam bersama seluruh warga sekolah, dan kegiatan membersihkan kelas dan lingkungan sekolah yang dilakukan secara rutin. Hal ini sejalan dengan pernyataan Amir (2016) bahwa sekolah untuk menanamkan karakter perlu menggunakan model penciptaan kondisi dan pemodelan untuk memberi contoh selain pembelajaran di dalam kelas, dan penggunaan model ini juga sebaiknya dilakukan secara rutin bahkan setiap hari.

Proses Pembelajaran Muatan Lokal Ekopedagogi Pendidikan Lingkungan Hidup

Pembelajaran terintegrasi PLH di SDN Lowokwaru 2 diberikan kepada siswa di dalam kelas dengan melaksanakan pembelajaran seperti biasanya, di luar kelas dengan mengajak siswa melakukan pembelaran lingkungan hidup di lingkungan sekolah, dan di luar sekolah dengan outing class untuk menambah pengetahuan siswa di luar sekolah. Metode pembelajaran yang digunakan dalam pembelajaranpun beragam, namun yang sering dipakai adalah metode ceramah dengan guru menyampaikan pembelajaran PLH secara lisan serta guru memegang kendali penuh akan kelas, metode demonstrasi dengan memperagakan suatu proses, situasi, atau benda tertentu pada saat pengajaran, metode diskusi dengan belajar pemecahan masalah yang dilakukan bisa antara guru dengan siswa atau siswa dengan siswa lainnya, metode tanya jawab dengan mengajak siswa berpartisipasi secara aktif pada pembelajaran untuk bertanya dan menjawab, dan metode penugasan berupa tugas-tugas dari buku tematik yang ada. Selain metode ini, guru juga menggunakan metode lainnya seperti permainan dan bermain peran yang disesuaikan dengan tema dan pembelajaran yang berlangsung. Proses pembelajaran muatan lokal ekopedagogi Pendidikan Lingkungan Hidup di SDN Lowokwaru 2 juga menggunakan media pembelajaran. Media pembelajaran yang dipakai diantaranya white board, spidol, penghapus, laptop, LCD, dan media 
pembelajaran asli yang diambil dari lingkungan. Namun, pada proses pembelajaran dari lima kelas yang dimasuki peneliti, hanya ada satu kelas yang memanfaatkan LCD dalam pembelajaran. Kelas lainnya lebih fokus melakukan pembelajaran dengan terpacu pada buku tematik saja. Penggunaan media pembelajaran bervariasi seharusnya diterapkan untuk membantu meningkatkan motivasi belajar siswa.

Proses pembelajaran di dalamnya tidak menutup adanya kemungkinan dari siswa yang melakukan pelanggaran. Di SDN Lowokwaru 2, apabila ada siswa yang melanggar suatu aturan guru biasanya memberikan teguran atau hukuman ringan berupa pendisiplinan yang di dalamnya juga terdapat Pendidikan Lingkungan Hidup. Misalnya ketika ada siswa telat masuk ke kelas, guru akan menghukum siswa untuk melarangnya masuk kelas sebelum membersihkan kelas atau lingkungan sekolah. Adanya pendisiplinan ini sesuai dengan pernyataan Choirun (2013) bahwa disiplin merupakan cara untuk mengajarkan siswa mengenai perilaku yang baik yang sesuai dengan lingkungan yang ditempati serta dalam proses pendisiplinan ini sebaiknya dilakukan tanpa melakukan hukuman yang berat agar siswa dapat menyadari kesalahannya dan dapat konsep diri bagi siswa dapat bertumbuh. Dengan cara pendisiplinan yang diberikan oleh SDN Lowokwaru 2, siswa dapat membentuk karakter di dalam dirinya tanpa ada paksaan yang dapat menyebabkan siswa justru merasa tidak dihargai dan berakhir dengan pemberontakan yang dilakukan siswa.

\section{Penilaian Pembangunan Karakter Siswa dalam Muatan Lokal Ekopedagogi Pendidikan Lingkungan Hidup}

Penilaian pembangunan karakter siswa dalam muatan lokal ekopedagogi Pendidikan Lingkungan Hidup (PLH) di SDN Lowokwaru 2 menggunakan penilaian otentik dari tugas, laporan, dan pengamatan kepada setiap siswa dengan menggunakan catatan anekdot. Kesimpulan dari hasil penelitian dinyatakan dalam bentuk pernyatan kualitatif yaitu BT (Belum Terlihat), MT (Mulai Terlihat), MB (Mulai Berkembang), dan MK (Membudaya) dan nantinya di rapot sekolah juga dilengkapi deskripsi perkembangan karakter setiap siswa. Penilaian ini sudah sejalan dengan Permendikbud No. 22 Tahun 2016 yang didalamya tertulis bahwa, "Penilaian proses pembelajaran menggunakan penilaian otentik (authentic assesment) yang menilai kesiapan peserta didik, proses , dan hasil belajar secara utuh". Namun berdasarkan hasil penelitian, guru masih memberatkan proses penilaian dari pembangunan karakter muatan lokal ekopedagogi Pendidikan Lingkungan Hidup (PLH), dikarenakan guru harus mengamati dan mencatatat perilaku sehari-hari setiap siswa. Selain itu penggunaan aplikasi rapot Kurikulum 2013 juga dirasa rumit oleh guru karena panduannya sering berubah setiap tahunnya sehingga diperlukan pemahaman kembali setiap ada perubahan yang menghambat proses penilaian.

\section{KESIMPULAN}

Berdasarkan hasil penelitian, dapat disimpulkan bahwa (1) Tujuan kurikulum muatan lokal ekopedagogi Pendidikan Lingkungan Hidup di SDN Lowokwaru 2 adalah menerapkan sekolah yang berbudaya peduli lingkungan dengan wujud warga sekolah yang bertanggung jawab dalam kegiatan pelindungan, pelestarian, dan pencegahan perusakan lingkungan dan sumber daya alam lewat tata kelola sekolah yang baik untuk mendukung pembangunan berkelanjutan, serta membekali siswa tentang kegiatan perlindungan, pelestarian, dan pencegahan perusakan lingkungan dan sumber daya alam, serta pelestarian fungsi lingkungan di sekolah. (2) Isi kurikulum muatan lokal ekopedagogi Pendidikan Lingkungan Hidup di SDN Lowokwaru 2 
adalah pengintegrasian materi mengenai lingkungan hidup dalam indikator pembelajaran dan kegiatan pembelajaran di mata pelajaran yang sesuai untuk diintegrasikan Pendidikan Lingkungan Hidup. (3) Sumber belajar yang digunakan di SDN Lowokwaru 2 adalah buku tematik, lingkungan sekitar, dan teladan perilaku guru. Di SDN Lowokwaru 2 belum terdapat modul khusus untuk Pendidikan Lingkungan Hidup dikarenakan mata pelajaran yang tidak berdiri sendiri. Oleh karena itu guru memili tuntutan untuk harus kreatif dalam menggunakan sumber belajar untuk pembelajaran muatan lokal ekopedagogi Pendidikan Lingkungan Hidup. (4) Proses pembelajaran muatan lokal ekopedagogi Pendidikan Lingkungan Hidup di SDN Lowokwaru 2 dilakukan secara terintegrasi. Proses pembelajaran dilaksanakan di dalam kelas, di luar kelas, serta di luar sekolah (outing class) dengan menyesuaikan pembelajaran dan tema yang sedang diajarkan. Untuk metode pembelajaran yang dipakai pada pembelajaran muatan lokal ekopedagogi Pendidikan Lingkungan Hidup di SDN Lowokwaru 2 adalah metode ceramah, demonstrasi, diskusi, tanya jawab, penugasan, dan metode lainnya seperti permainan dan bermain peran. Sedangkan media pembelajaran yang dipakai adalah whiteboard, spidol, penghapus, laptop, LCD, dan media pembelajaran asli yang diambil dari lingkungan. Walaupun begitu penggunaan media pembelajaran di SDN Lowokwaru 2 belum terlaksana secara optimal. Untuk hukuman siswa apabila dalam proses pembelajaran melakukan pelanggaran, guru akan memberikan teguran atau hukuman ringan untuk membentuk karakter siswa yang peduli terhadap lingkungan. (5) Penilaian pembangunan karakter siswa dalam muatan lokal ekopedagogi Pendidikan Lingkungan Hidup di SDN Lowokwaru 2 menggunakan penilaian otentik. Penilaian otentik diambil dari nilai tugas, laporan, dan pengamatan kepada setiap siswa menggunakan catatan anekdot yang pada akhirnya dapat disimpulkan dalam bentuk pernyataan kualitatif dan dapat dideskripsikan di rapot. Namun, guru SDN Lowokwaru 2 mengeluhkan apabila proses penilaian pembangunan karakter termasuk berat dikarenakan guru harus mengamati dan menilai perilaku sehari-hari setiap siswa. Selain itu penulisan rapot Kurikulum 2013 dalam aplikasi juga menjadi keluhan. Hal ini dikarenakan panduan penulisan rapot yang sering berubah.

Adapun saran yang diberikan yaitu: (1) Pemerintah diharapkan tidak sering berganti panduan penulisan rapot Kurikulum 2013 yang menyebabkan guru harus berulang kali mempelajari panduan sehingga waktu penulisan rapot tidak terbuang untuk pemahaman penulisan rapot saja, (2) Guru SDN Lowokwaru 2 sebaiknya lebih sering menggunakan media pembelajaran bervariasi dan sumber belajar langsung dari lingkungan saat pembelajaran muatan lokal ekopedagogi Pendidikan Lingkungan Hidup agar tidak terpaku pada buku tematik saja, (3) Penilaian pembangunan karakter dengan menggunakan penilaian autentik yang dirasa memberatkan guru sebaiknya diatasi dengan persiapan pembelajaran mulai dari RPP hingga evaluasi pembelajaran yang diperhitungkan dan dipersiapkan secara matang dari awal agar penilaian autentik tidak dirasa menjadi kendala lagi bagi guru.

\section{DAFTAR PUSTAKA}

Anonim. 2003. Undang-Undang RI No. 20 Tahun 2003 tentang Sistem Pendidikan Nasional

Anonim. 2014. Peraturan Menteri Pendidikan dan Kebudayaan Republik Indonesia No. 79 Tahun 2014 tentang Muatan Lokal Kurikulum 2013

Anonim, 2016. Peraturan Menteri Pendidikan dan Kebudayaan No. 22 Tahun 2016 tentang Standar 
Proses Pendidikan Dasar dan Menengah

Aulina, C.N. 2013. Penanaman Disiplin pada Anak Usia Dini. PEDAGOGIA: Jurnal Pendidikan, 2(1), 36-49

Hamzah, Amir. 2016. Profil Pembelajaran Karakter di Sekolah Dasar (Studi Kasus pada Sekolah Dasar di Kota Sampang). JINOTEP, 3(1), $31-50$
Idi, Abdullah. 2010. Pengembangan Kurikulum : Teori dan Praktik. Jogjakarta : Ar-Ruzz Media

Kementrian Pendidikan Nasional. 2010. Pengembangan Budaya dan Karakter Bangsa. Jakarta:Kementrian Pendidikan Nasional

Sukmadinata, Nana S. 2010. Pengembangan Kurikukulum dan Praktek. Bandung: Remaja Rosdakarya 